\title{
LOWER LIMB FORCE, POWER AND PERFORMANCE IN SKATEBOARDING:
}

\section{AN EXPLORATORY STUDY}

\section{DRA. CLÁUDIA TARRAGÔ CANDOTTI}

Doutora em Ciências do Movimento Humano pela UFRGS e Professora Adjunta da UFRGS ministrando disciplinas na graduação (Educação Física e Fisioterapia) e no Programa de Pós-Graduação em Ciência do Movimento Humano - ESEF/UFRGS (Mestrado e Doutorado).

E-mail: claudia.candotti@ufrgs.br

\section{DR. JEFFERSON FAGUNDES LOSS}

Doutor em Engenharia Mecânica pela UFRGS e Professor Associado da UFRGS ministrando disciplinas na graduação (Educação Física, Fisioterapia e Enfermagem) e no Programa de PósGraduação em Ciência do Movimento Humano - ESEF/UFRGS (Mestrado e Doutorado).

E-mail: jefferson.loss@ufrgs.br

\section{GRAD. RÉVISSON ESTEVES SILVA}

Graduado em Educação Física pela Universidade do Vale do Rio dos Sinos.

E-mail: revisson@hotmail.com

\section{MS. MÔNICA DE OLIVEIRA MELO}

Doutoranda em Ciências do Movimento Humano pelo Programa de Pós-Graduação em Ciências do Movimento, da Universidade Federal do Rio Grande do Sul. Graduada em

Educação Física pela Universidade do Vale do Rio dos Sinos. Professora da

Universidade de Caxias do Sul ministrando disciplinas na graduação de Educação Física.

Membro do Núcleo de Pesquisa em Artes e Ciências do

Movimento Humano da Universidade da Universidade de Caxias do Sul

E-mail:melo.monica@terra.com.br

\section{GRAD. RICARDO BARRETO TEIXEIRA}

Graduado em Educação Física pela Universidade do Vale do Rio dos Sinos.

E-mail: rssaoleo@hotmail.com

\section{GRAD. GUSTAVO BECKER DELWING}

Graduado em Educação Física pela Universidade do Vale do Rio dos Sinos.

E-mail: gdelwing@yahoo.com.br

\section{MS. MATIAS NOLL}

Mestre em Ciências do Movimento Humano pelo Programa de Pós-Graduação em Ciências do Movimento Humano, da Universidade Federal do Rio Grande do Sul. Graduado em Educação Física pela Universidade do Vale do Rio dos Sinos.

E-mail: matiasnoll@yahoo.com.br 


\section{ABSTRACT}

The purpose of this study was to identify the relationship between the height reached when performing the Ollie maneuver and the muscle force and power of the lower limbs required by beginner level skateboarders. Ten practitioners of Street category, with at least two years experience and who participate in competitions in Beginner, Amateur II or Amateur I categories were submitted to three tests: (I) maximal voluntary contraction of the knee and hip extensor muscles; (2) vertical jump tests, Counter Movement Jump (CJ) and Squat Jump (SJ); and (3) the maximum height achieved during the Ollie maneuver. The results demonstrate that the variance of the Ollie maneuver $(p<0.05)$ is explained by the power estimated with the $C J$ (76.3\%); and the maximal force of the knee extensor muscle (50.6\%). These results suggest that the variable power is strongly associated with the performance of the Ollie maneuver.

KEYWORDS: Athletic performance; sports; skating; Ollie maneuver.

\section{INTRODUCTION}

In recent years the practice of skateboarding has become increasingly popular as well as more professional (DETERMAN et al., 2010). In 2002, Brazil had approximately 2.7 million practitioners of skateboarding, a figure that has certainly grown to date (ARMBRUST; LAURO, 20I0). According to the Brazilian Confederation of Skateboarding (CBSK) there are about 10,000 athletes who participate of championships in Brazil and, despite this apparent growth of skateboarding, there are few published studies on the performance of the skaters and skateboarding (CONFEDERAÇÃO BRASILEIRA DE SKATE, 201 I).

Although there are many modalities of skateboarding, such as, Street, Mountainboard, Downhill and Vertical, the first is the most popular among practitioners around the world. Street style consists of skating on obstacles that can be found in cities like monuments, benches, railings, low walls, stairs, ramps in driveways, stages, holes, uneven ground, slopes, inclined surfaces and skateparks, which are locations designed to simulate urban architecture (CONFEDERAÇÃO BRASILEIRA

DE SKATE, 201 I ). The skater can overcome any such obstacles by executing different types of maneuvers, which consist of jumping with the skateboard, and may include flipping the skateboard and/or turning the athlete's body (REED, 2002). In street skateboarding, the most useful and basic maneuver that a skateboarder needs to know is the Ollie, which is considered the foundation on which most other maneuvers are based (TESLER, 2000).

The Ollie is the basic skateboarding maneuver and consists of a jump where the skate and the athlete rise from the ground and return in continuous movement (BOBBERT et al., 1986). Figure I illustrates the Ollie maneuver. It allows the skater to pass over, mount or slide along obstacles and requires considerable 
skill and timing (BRIDGMAN; COLLINS; COLLINS, 1992) and most other maneuvers are combinations of the Ollie with turns of the skateboard and the athlete's body (CANAVAN; VESCOVI, 2004). Given that the Ollie maneuver is involved in most skateboarding movements it is important to study it in order to improve the performance of the athletes.

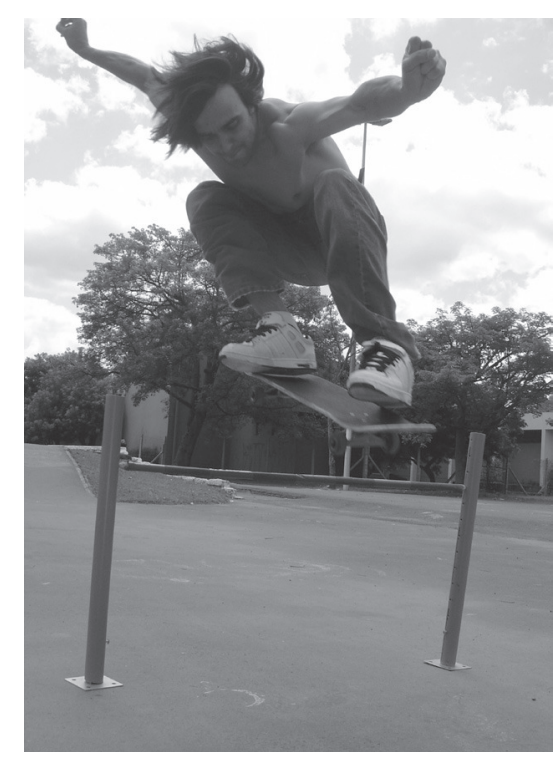

Figure I. Subject performing the Ollie maneuver

Various sports include the vertical jump among their fundamental gestures. In view of its importance, several studies have attempted to explain the variables that determine the performance of this gesture (RAVN et al., 1999; HASSON et al., 2004). In the context of skateboarding, scientific research has only begun very recently, and skaters rarely have access to scientifically-based training. The performance of a movement depends on the technique and the muscular force employed (FOLLAND; WILLIAMS, 2007), but not only on these variables. In fact, the performance of a jump, for example, involves variables of varying nature, including: conditioning variables, such as maximal strength and power; physiological variables, such as neural adaptations (MORITANI, 1993); motor control variables, such as the coordination of neuromuscular contraction (ENOKA, 1988); neuro-mechanical variables, such as the capacity to use the stretching-shortening cycle (SSC) (HASSON et al., 2004); mechanical variables, 
such as the joint angles used to acquire jump impulse (RAVN et al., 1999); and anthropometric variables, such as the body mass of the individual. In the case of the Ollie, there are also extrinsic variables such as the positioning of the feet on skateboard, the size and angle of inclination of the tail (posterior part of skateboard), the weight of the skateboard and the height of the shape (wooden platform covered by sandpaper) in relation to the ground. However, the contribution of each of these variables towards the performance of the Ollie maneuver remains unknown, though muscle force and power probably play a significant part in performance of this maneuver (FUKASHIRO; KOMI, 1987).

Besides this issue, there are many others regarding the performance of the Ollie maneuver that remain unanswered. Therefore, the purpose of this study was to carry out an initial exploratory analysis in order to identify the relationship between the height reached when performing the Ollie maneuver and the muscle force and power of the lower limbs required by beginner level skateboarders in order that trainers and skateboarders might benefit from this information.

\section{MATERIALS AND METHODS}

\section{SUBJECTS}

Ten males with a mean age of $18.1 \pm 3.7$ years; body mass $62.7 \pm 9.5$ $\mathrm{kg}$; body fat 12.5 $\pm 1.8 \%$ and height $172.2 \pm 10.6 \mathrm{~cm}$ volunteered to participate in the experiment. All subjects are practitioners of Street category, having at least two years experience and participate in competitions at Beginner (over 14 years of age or with a maximum of 4 years competing in this category), Amateur II (with a maximum of five years competing in this category, regardless of age) or Amateur I (with more than five years competing in Amateur 2, regardless of age) categories (CONFEDERAÇÃO BRASILEIRA DE SKATE, 20II). The subjects were informed of the procedures of the research and signed a free informed consent term prior to participation. The study was approved by the local ethics committee.

\section{ISOMETRIC MAXIMAL VOLUNTARY CONTRACTION (IMVC)}

IMVC of the hip and knee extensor muscles was performed three times for each leg, for approximately $5 \mathrm{~s}$, with a two-minute interval between trials. The right lower member was always the first to be evaluated and a uni-dimensional load cell was attached to a metallic device, so that the direction of the measured isometric force was perpendicular to the evaluated limb. The subjects received strong verbal 
encouragement. To assess the knee extensor muscle force (KE), knee isometric extension was performed in a seated position, with a back rest, thighs securely fixed by straps with the knees at an angle of $90^{\circ}$. All the subjects were fastened at the level of the ankles by a leather belt attached to the load cell. To assess the muscle force of the hip extensors ( $\mathrm{HE})$, a hip isometric extension was performed on a bench, with the subjects supporting the trunk on the bench with the lower back securely fixed by straps, while the legs were suspended over the edge with the knees flexed. All the subjects were fastened at the level of the thighs by a leather belt attached to the load cell. Figure 2 shows a diagram of the experimental setup. The force signals were obtained using a load cell (EMG System do Brazil Ltda, São Jose dos Campos) connected to a $200 \mathrm{MHz}$ Pentium microcomputer, by means of an A/D converter (EMG System do Brazil Ltda, São Jose dos Campos). The signals were obtained with AqDados software (Lynx Electronic Technology Ltda, São Paulo), with a sampling frequency of $500 \mathrm{~Hz}$. Although the test was isometric and the Ollie maneuver requires dynamic contraction, a strong correlation has recently been shown to exist between the peak isometric force and the performance of the high jump (KAWAMORI et al., 2006). Additionally, Folland et al. (2005) showed that a dynamic training leads to an increase in isometric force. Furthermore, although a dynamic test is more suitable for assessing a dynamic situation, it is often the case that the test result is represented by a single value, such as isokinetic peak torque (COMETTI et al., 200 I ; HAMILTON et al., 2008). The evidence from the literature suggests that a simple isometric test is representative of the dynamic situation.
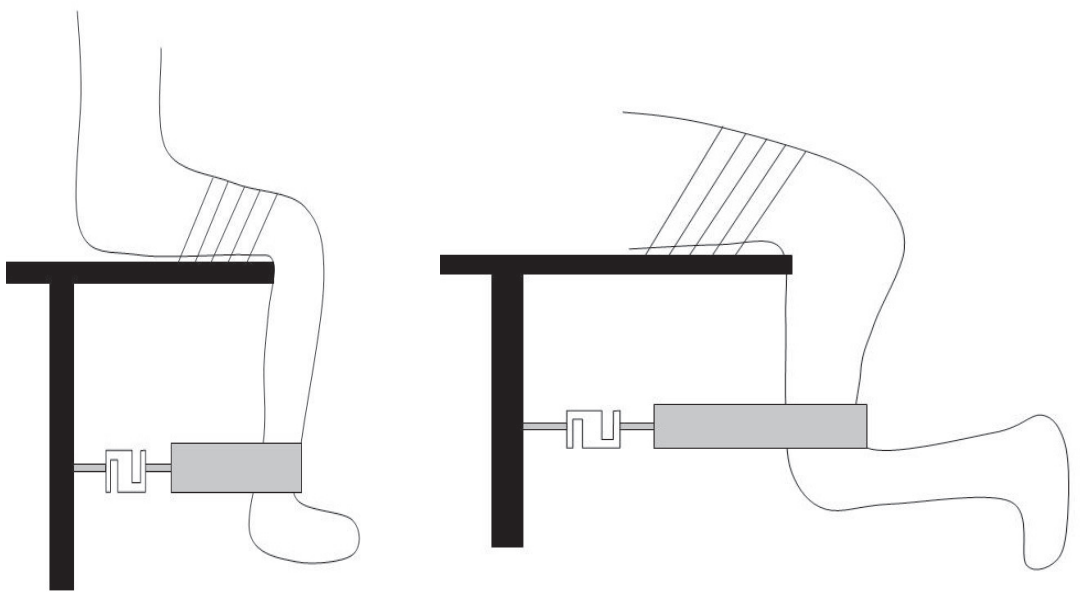

Figure 2. Experimental setup of isometric knee extension force (a) and hip extension force (b) measurements. 
Two types of jump assessments were performed by each subject: I) squat jump (SJ) and 2) counter-movement jump (CJ). The participants were instructed to use their hands to help the impulsion during the jumps. After three sub maximal warm-up jumps, the subject did a series of at least 3 maximal jumps with two-minute rest intervals between jumps. The $\mathrm{S}$ J series was done first. In order to assess the $\mathrm{S}$, the subjects were instructed to jump as high as possible starting from a squatting position with the knees at $90^{\circ}$. A successful trial was one where there was no sinking or countermovement prior to the execution of the jump. In order to assess the C], the subjects were instructed to sink as quickly as possible and then jump as high as possible. The maximum height was registered by points (marks) made on the wall with chalk dust on the fingers of the hands of the subjects.

\section{OLLIE MANEUVER EVALUATION}

The Ollie starts with the skater placing his front foot in the middle of the shape (wooden board covered with sandpaper, which supports the skater's feet) and his back foot on the tail (back part of the skateboard). As he approaches the object to be jumped over, he performs a squat and then starts accelerating upward, extending the torso and knees, and raising the arms. Then, he pushes the tail down with the back foot so that the skateboard turns on the rear axle, lifting the nose (front of the shape). When the time the tail hits the floor, applying force against the ground, there is a force response in the opposite direction, causing the skate to rise from the floor and starting the flight phase. At the same time, the body of the skater which is already in the lift phase, rises in sync with the skateboard, the trajectory of which controlled by the front foot. In the final phase, the skater cushions the fall by flexing the trunk and legs, ensuring a safe and controlled landing (TESLER, 2000; FREDERICK et al., 2006).

During the course of the Ollie (Figure I), the center of mass of the skater's body follows a smooth parabolic trajectory, although each body segment follows a complex trajectory. The arms are raised in order to raise the jump and the center of mass of the legs rises 55\% more than the total center of mass in order to pass over the obstacle (BRIDGMAN; COLLINS; COLLINS, I 992; FROISLAND; MATSON; STUTZMAN, 2004). Finally, the height of the Ollie is a result of the upward acceleration that occurs at the start of the jump, so an athlete who improves his performance in the Ollie by increasing the ability to accelerate upward will be also obtain an increase in the maximum height achievable in all other jump maneuvers (TESLER, 2000). 
In order to measure the maximum height achieved during the Ollie maneuver an apparatus consisting of a horizontal bar supported at each end - similar those used to evaluate high jumps during competitions -, was specifically developed to represent an obstacle to jump over (FIGURE I). This device made it possible to regulate the height. First, each subject was asked to estimate their maximum height and perform a series of three warm-up jumps over the device at $50 \%$ of the predicted maximum height. After, the height of device was set to $10-20 \mathrm{~cm}$ below the predicted maximum height and the test consisted of clearing this height followed by stepwise increases in height of $5 \mathrm{~cm}$ with two-minute intervals between attempts, with a maximum of four attempts at each height. When the subject was not successful at four consecutive jumps, the test was finalized and the best height registered. The validity of the test was verified during a pilot study $(n=15)$ using test and re-test procedures with an interval of seven days between them. A paired t-test showed no difference between the two test days $(p=0.467)$ and the results showed a high and significant correlation $(r=0.96 ; p<0.00 I)$, indicating the validity of the Ollie evaluation protocol.

\section{DATA ANALYSIS}

Data analysis of force signals during IMVC test was performed using the AqDados 7.0 data acquisition system (Lynx Electronic Technology Ltda, São Paulo). The average force values obtained from the three trials of each IMVC test was calculated. The maximum value obtained in the $\mathrm{Ollie}$ evaluation was registered. The highest values obtained during the CJ and SJ tests were considered. These values were used to predict the lower limb power using equations I and 2 (HARMAN et al., I99I, JOHNSON; BAHAMONDE, 1996).

$$
\begin{aligned}
& P C J=(78.5 \cdot C J)+(60.6 \cdot m)-(\mid 5.3 \cdot h)-1308 \\
& P S J=(6 \mid .9 \cdot S J)+(36 \cdot m)-(\mid 822)
\end{aligned}
$$

where:

PC): power of lower limbs from CJ (W)

PS): power of lower limbs from SJ (W)

C): height registered from CJ $(\mathrm{cm})$

$\mathrm{SJ}$ : height registered from $\mathrm{SJ}(\mathrm{cm})$

m: body weight $(\mathrm{kg})$

h: height $(\mathrm{cm})$. 
The intensity of the multicollinearity between the independent variables (C), SJ, PCJ, PSJ, KE, HE) was analyzed using the Pearson correlate bivariate test. Given that the high levels of the coefficients found in the correlations matrix indicated multicollinearity and the small sample size, in order to assess which independent variable was best able to predict the dependent variable (performance of the Ollie Jump) it was decided to apply simple linear regression for each independent variable. Thus, the values obtained for the independent variables (IV) can, in the generic prediction equation (3), be substituted so they predict performance in the Ollie maneuver. The data were submitted to statistical treatment using version I 5 SPSS software. Significance was set at $p<0.05$.

Ollie $=$ const $+\beta \cdot \mathrm{IV}$

\section{RESULTS}

Table I presents the mean values and standard deviations of the vertical jump tests, Ollie jump heights, the forces of the knee and hip extensor muscles and lower member muscular power. No significant difference was found between the force values of the dominant and non-dominant member and the lower member muscular power was greater when it was calculated using the CJ height values.

Table I. Mean values and standard deviations of squat jump (SJ), countermovement jump (CJ), Ollie height and muscular force and power values

\begin{tabular}{|c|c|c|c|}
\hline \multicolumn{4}{|l|}{ Jumps (cm) } \\
\hline SJ & C) & & Ollie \\
\hline $35.3 \pm 4.7$ & $44.4 \pm 6.3$ & & $64.5 \pm 9.2$ \\
\hline \multicolumn{4}{|c|}{ Force (kg) } \\
\hline KED & HED & KEND & HEND \\
\hline $43.2 \pm 9.9$ & $79.2 \pm 26.3$ & $44.2 \pm 13.8$ & $8.6 \pm 27.1$ \\
\hline \multicolumn{4}{|c|}{ Power (W) } \\
\hline PSJ & & PCJ & \\
\hline $2615 \pm 516$ & & $3335 \pm 855$ & \\
\hline
\end{tabular}

Legend: (KED = knee extensors, dominant side; HED = hip extensors, dominant side; KEND = knee extensors, non-dominant side; HEND = hip extensors, non-dominant side; PSJ and PCJ = lower member power estimated from SJ and CJ, respectively).

Simple linear regression analysis revealed the prediction potential of each one of the independent variables. In Table 2, the results of these analyses are shown 
according to their prediction potential. Therefore, given that the $r^{2}$ values indicate the percentage of variance of the dependent variable that can be explained by the independent variable, the results demonstrated that $76.3 \%$ of variance in the Ollie jump can be explained by the PCJ, or further, $76.1 \%$ by the corporal mass and $50.6 \%$ by the knee extensor muscle force on the dominant side (KED). Similarly, hip extensor force on the non-dominant side (HEND) and squat-jump (SJ) height cannot be used to explain performance of the Ollie maneuver.

Table 2. Predictor equation parameters with respective $R$ square, $F$ and significance level of each independent variable in the performance of the Ollie

\begin{tabular}{llllll}
\hline & $r^{2}$ & const & $\beta$ & $F$ & $P$ \\
\hline PCJ & 0.763 & 32.96 & 0.009 & 25.7 & 0.001 \\
PSJ & 0.684 & 25.66 & 0.015 & 17.3 & 0.003 \\
KED & 0.506 & 35.96 & 0.660 & 8.1 & 0.021 \\
HED & 0.488 & 44.99 & 0.246 & 7.6 & 0.025 \\
CJ & 0.457 & 19.96 & 0.676 & 6.7 & 0.032 \\
KEND & 0.423 & 46.57 & 0.223 & 5.8 & 0.042 \\
HEND & 0.358 & 46.77 & 0.401 & 4.4 & 0.068 \\
SJ & 0.193 & 34.27 & 0.439 & 1.9 & 0.204 \\
\hline
\end{tabular}

Legend: (const $=$ constant values obtained from the linear regression for each variable; $=$ regression coefficient; PCJ = power of lower limbs from CJ; PSJ = power of lower limbs from SJ; KED = knee extensors, dominant side; HED = hip extensors, dominant side; $\mathrm{C}$ = counter-movement jump; KEND = knee extensors, non-dominant side; HEND = hip extensors, non-dominant side; $\mathrm{S}$ = squat jump).

\section{DISCUSSION}

The purpose of this study was to identify the relationship between the height reached when performing the Ollie maneuver and the muscle force and power of the lower limbs required in beginner level skateboarders. The results showed that all independent variables, except the HEND and SJ, are significantly associated with performance in the Ollie maneuver (Table 2). Given that the CJ test, like the Ollie jump test, involves the stretch-shorten cycle, a higher correlation was expected between the Ollie maneuver and the CJ as well as the PCJ. The results indicated that $76.3 \%$ of the performance in the Ollie maneuver is determined by the lower 
limb power (PCJ), but only $45.7 \%$ by the height reached during the C] test. This difference is probably due to the fact that the PJC uses, together with the C], individual anthropomorphic characteristics such as body mass and height of the skateboarders.

Since the height of the Ollie, depends on the increased acceleration of the athlete 's body and the capacity to generate force and ability in the application of that force (TESLER, 2000; FROISLAND; MATSON; STUTZMAN, 2004), a close relation between the performance of the Ollie and the power of the experienced athletes was also expected. Furthermore, it was believed that this relation would be greater for the PCJ than for the PSJ. The difference between the PCJ and PSJ was $7.9 \%$, suggesting an enhanced capacity in the use of the elastic structures may be relevant for the performance of the Ollie.

Nevertheless, the correlation between the maximum isometric strength and the height achieved in the Ollie maneuver was not as high as expected. Although some authors have shown that the development of maximum strength in the quadriceps can also contribute to increased muscle power assessed by tests without countermovement jump (YOUNG; JENNER; GRIFFITHS, 1998; NAGANO et al., 2005), the results of this study showed that the dynamic maximum force was not correlated with the height reached in Ollie maneuver. Here, it can be speculated that as it involves the action of several joints, performance during the jump depends on many specific independent interrelated variables, such as motor control, intramuscular coordination, strength levels, the degree of muscle power and the execution technique, among others (WEISS et al., 1997). While for some authors the height of the jump height depends largely on the muscular strength of the quadriceps (ARAGÓN-VARGAS; GROSS, 1997), for others the ability to transfer mechanical energy from the proximal to the distal segments is much more important when determining the vertical jump performance (KOLLIAS et al., $200 \mathrm{l}$ ).

In spite of, our results are in accordance with other studies in which knee extensor muscle force was shown to contribute $50 \%$ towards the performance of the vertical jump (NAGANO, 2005), while in the present study the correlation was $50.6 \%$ for this muscular group in the Ollie maneuver. The force values of the knee and hip extensors of the non-dominant leg presented a lower correlation to the height achieved in the Ollie maneuver, and the knee extensor force values were insignificant. This suggests that the force that the athlete applies to the skateboard is greater in the dominant leg and that the hip extensor muscles make a greater contribution to the performance achieved in the Ollie maneuver than the knee extensor muscles. The results obtained for power seem to be in accordance with other studies (BOBBERT et al., 1986; FUKASHIRO; KOMI, I987; NAGANO, 2005).

When observing skateboarders, it appears to be a pre-requisite that in order for the athlete to execute maneuvers like the Ollie they must control the skateboard 
on level surfaces, on ramps, when moving forward or backward and turning left or right. The technical qualities that a street skateboarder, for example, needs to develop in all kinds of surfaces and on the two bases appear to be: control of the board, pushing at speed, slide and jump maneuvers, like the Ollie. In the present study, during the evaluation of the Ollie maneuver, each skateboarder had a different arm movement technique. Consequently, as arm movement may represent a significant increase in height during jumps (LESS; VANRENTERGHEM; CLERCQ, 2004), the extent to which such movements influence the Ollie would be an interesting area for further research. Such a study would make it possible to investigate whether or not there would be any advantage for an athlete to change their arm movement technique in order to obtain improved performance in the Ollie. Nevertheless, new studies on the performance of the Ollie maneuver should consider not only technical control of the arm movements, but also other important features, such as diet, ergogenic resources and type of skateboard used. Therefore, caution should be adopted in applying these findings to the general population of skateboarders.

The results of the present study suggest that, for beginner level skateboarders, the variable power is strongly associated with the performance of the Ollie maneuver and that using this information, trainers and skateboarders can predict performance in the Ollie maneuver and improve training programs. Also, one can speculate that maximum dynamic strength could be an important limiting variable on the performance assessed in this study. However, studies with a larger number of individuals are recommended to confirm the importance of these variables. These findings should also form the basis for future studies that would help science better understand the relationship of the strength and power variables in the performance of the Ollie maneuver.

In summary, the preliminary results of the present study suggest that the lower limb power calculated using the equations ( I ) and (2) appears to be a better predictor of performance in the Ollie maneuver than isometric lower limb force. These results corroborate research indicating that the mechanical power produced by muscles and estimated based on the height of the vertical jumps achieved or using information supplied by a force platform system, can be considered important for success in athletic performance (STONE et al., 2003).

\section{CONCLUSION}

Evaluation of performance during Ollie maneuver demonstrated that, on average, the skaters were able to clear an obstacle $64.5 \mathrm{~cm}$ high and that $76.3 \%$ of the variance in the performance of the Ollie maneuver can be explained by the countermovement jump, $76.1 \%$ by the body mass and $50.6 \%$ by the knee 
extensor muscle force on the dominant side. By contrast, hip extensor force on the non-dominant side and squat-jump height cannot be used to explain performance of the Ollie maneuver. These results suggest that performance of the Ollie maneuver in skateboarding basically depends on muscle power, which represents useful information for athletes and coaches.

\section{Força, potência e desempenho dos membros inferiores no skate: um estudo exploratório}

RESUMO: O objetivo deste estudo foi identificar a relação entre a altura atingida ao realizar a manobra Ollie e a força e potência muscular dos membros inferiores de skatistas iniciantes. Dez praticantes da modalidade Street, com no mínimo dois anos de experiência e participantes de competições nas categorias Iniciante, Amador II or Amador I foram submetidos a três testes: ( I ) contração voluntária máxima dos músculos extensores do joelho e quadril; (2) testes de salto vertical, Counter Movement Jump (CJ) e Squat Jump (SJ) e (3) a altura máxima atingida durante a manobra Ollie. Os resultados demonstram que a manobra Ollie ( $p<0,05)$ é explicada pela potência estimada com o CJ (76,3\%) e pela força máxima dos músculos extensores do joelho (50,6\%). Estes resultados sugerem que a variável potência está fortemente associada com a performance da manobra Ollie.

PALAVRAS-CHAVE: Desempenho atlético; esportes; skate; manobra Ollie.

\section{Fuerza, potencia y rendimiento de las extremidades inferiores en el skate: un estudio exploratorio}

RESUMEN: El objetivo de este estudio fue identificar la relación entre la altura alcanzada con la maniobra Ollie y la fuerza y el potencia muscular de las extremidades inferiores de patinadores principiantes. Diez atletas de la modalidad Street con al menos dos años de experiencia y participar en las competiciones en las categorías de principiante, amateur I y amateur II fueron sometidos a tres pruebas: (I) la máxima contracción voluntaria de los músculos extensores de la rodilla y la cadera, (2) las pruebas de salto vertical, Counter Movement Jump (CJ) y Squat Jump (SJ), y (3) la altura máxima durante la maniobra Ollie. Los resultados demuestran que la maniobra Ollie $(p<0,05)$ se explica por la potencia estimada con el CJ (76,3\%) y la fuerza máxima de los músculos extensores de la rodilla (50,6\%). Estos resultados sugieren que la potencia muscular está fuertemente asociada con el rendimiento de la maniobra de Ollie.

PALABRAS-CLAVES: Rendimiento atlético; deportes; paginación; maniobra Ollie.

\section{REFERENCES}

ARAGÓN-VARGAS, L.; GROSS, M. Kinesiological factors in vertical jump performance: differences among individuals. Journal of Applied Biomechanics, Champaign, v. 13, p. 24-44, feb. 1997. 
ARMBRUST, I; LAURO, FAA. O Skate e suas possibilidades educativas. Motriz, Rio Claro, v. 16, n. 3, p.799-807, jul./set. 2010.

BOBBERT, M. F. et al. Biomechanical analysis of drop and countermovement jumps. European Journal of Applied Physiology and Occupational Physiology, Berlin, v. 54, n. 6, p. 566-73. 1986.

BRIDGMAN, S.; COLLINS, J.; COLLINS, D. F. Human body motion in an ollie. The Physics Teacher, College Parks, n. 30, p. 498-499. 1992.

CANAVAN, P. K.; VESCOVI, J. D. Evaluation of power prediction equations: peak vertical jumping power in women. Medicine and Science in Sports and Exercise, Hagerstown, v.36, n.9, p. I 589-93, sep. 2004.

COMETTI, G. et al. Isokinetic strength and anaerobic power of elite, subelite and amateur french soccer players. International Journal of Sports Medicine, Stuttgart, v. 22, p. 45-5I, jun. 2001 .

CONFEDERAÇÃO BRASILEIRA DE SKATE, 201 I. Disponível em: <http://mww.cbsk.com.br>. Acesso em: 20 set. $201 \mathrm{I}$.

DETERMAN, J. J. et al. High impact forces in skateboarding landings affected by landing outcome. Footwear Science, London, v. 2, n. 3, p. 159-170, sep. 2010.

ENOKA, R.M. Muscle strength and its development. New perspectives. Sports Medicine, Auckland, v. 6, n. 3, p. I46-68, sept. 1988.

FILIPPIN, N. T. et al. Repetibilidade de medidas isocinéticas dos músculos adutores e abdutores do quadril. Revista Brasileira de Educação Física e Esporte, São Paulo, v. 20, n. 2, p. I 3 I-39, abr.jun. 2006.

FOLLAND, J. P. et al. Strength training: isometric training at a range of joint angles versus dynamic training. Journal of Sports Science, London, v. 23, n. 8, p. 817-24, aug. 2005.

FOLLAND, J. P.; WILLIAMS, A. G. The adaptations to strength training: morphological and neurological contributions to increased strength. Sports Medicine, London, v. 37, n. 2, p. | 45-68, feb. 2007.

FREDERICK, E. C. et al. Biomechanics of skateboarding: kinetics of the Ollie. Journal of Applied Biomechanics, Champaign, v. 22, n. I, p.33-40, feb. 2006.

FROISLAND, A.; MATSON, J.; STUTZMAN, M. The skateboard Ollie: a biomechanical analysis. Humboldt State University, Movement Analysis Laboratory, Undergraduate Projects Kins 382, 2004. Disponível em: <http://www.humboldt.edu/ movement/>. Acesso em: 13 out. 2010.

FUKASHIRO, S.; KOMI, P. Joint moment and mechanical power flow of the lower limb during vertical jump. International Journal of Sports Medicine, Stuttgart, n. 8, p. I5-21, mar. 1987. 
HAMILTON, R.T. et al. Triple-hop distance as a valid predictor of lower limb strength and power. Journal Athletic Training, Dallas, v. 43, n. 2, p. I44- I5I, mar/apr. 2008.

HARMAN, E. A. et al. Estimation of human power output from vertical jump. Journal of Strength and Conditioning Research, Colorado Springs, v. 5, n. 3, p. I16-120, fev. 1991.

HASSON, C. J. et al. Neuromechanical strategies employed to increase jump height during the initiation of the squat jump. Journal of Electromyography and Kinesiology, Netherlands, v. |4, n. 4, p. 515-521. 2004.

JOHNSON, D. L.; BAHAMONDE, R. E. Power output estimate in university athletes. Journal of Strength and Conditioning Research, Colorado Springs, v. I0, n.3, p. I6I-166, jan. 1996.

KAWAMORI, N. et al. Peak force and rate of force development during isometric and dynamic mid-thigh clean pulls performed at various intensities. Journal of Strength and Conditioning Research, Colorado Springs, v.20, p.483-49I, aug. 2006.

KOLLIAS, I. et al. Using principal components analysis to identify individual differences in vertical jump performance. Research Quarterly for Exercise and Sport, Reston, v.72, n. I, p.63-67, mar. 2001.

LEES, A.; VANRENTERGHEM, J.; CLERCQ, D. D. Understanding how an arm swing enhances performance in the vertical jump. Journal of Biomechanics, New York, v. 37, n. I2, p.1929-1940, dec. 2004.

MORITANI, T. Neuromuscular adaptations during the acquisition of muscle strength, power and motor tasks. Journal of Biomechanics, New York, v. 26, n. I, p. 95- 107, suppl. 1993.

NAGANO, A. et al. Force, work and power output of lower limb muscles during human maximal-effort countermovement jumping. Journal of Electromyography and Kinesiology, New York, v. I5, n. 4, p. 367-376, aug. 2005.

RAVN, S. et al. Choice of jumping strategy in two standard jumps, squat and countermovement jump effect of training background or inherited preference? Scandinavian Journal of Medical and Science in Sports, Copenhagen, v. 9, n. 4, p. 201-208, aug. 1999.

REED, C. Skateboarding: the sport, explained. 2002. Disponível em: < http://skateboarddirectory.com/articles/480283_skateboarding_the_sport.html >. Acesso em: 10 set. 2010.

STONE, M. H. et al. Power and maximum strength relationships during performance of dynamic and static weighted jumps. Journal of Strength and Conditioning Research, Colorado Springs, v. 17, n. I, p. I40-147, feb. 2003.

TESLER, P. Asphalt acrobats. Scientific American Presents. 2000.

WEISS, L.W. et al. Predicting depth vertical jumping distances. Isokinetics and Exercise Science, Amsterdan, v.7, n. 4, p. I51-159, jan. 1998. 
YOUNG, W.; JENNER, A.; GRIFFITHS, K. Acute enhancement of power performance from heavy squat loads. Journal of Strength and Conditioning Research, Colorado Springs, v. 22, n. I, p. 82-84, jan. 1998.

Recebido: 28 fev. 2011 Aprovado: 24 nov. 2011

Address for correspondence: Cláudia Tarragô Candotti Rua Fernando Osório, 1887 Porto Alegre - RS - Brasil CEP: $91720-330$

Fone: (5I) 3308-586।

E-mail: claudia.candotti@ufrgs.br 